\title{
BioMedicine
}

\section{Bioactivities and action mechanisms of active compounds from Hottuynia cordata THUNB on human lung cancer cells}

Follow this and additional works at: https://www.biomedicinej.com/biomedicine

Part of the Alternative and Complementary Medicine Commons, Life Sciences Commons, and the Medical Sciences Commons

(c) (i)

This work is licensed under a Creative Commons Attribution 4.0 License.

\section{Recommended Citation}

Chen, Yuh-Fung; Chang, Wen-Hsin; Tsai, Huei-Yann; Lee, Min-Min; and Wu, Tian-Shung (2021) "Bioactivities and action mechanisms of active compounds from Hottuynia cordata THUNB on human lung cancer cells," BioMedicine: Vol. 11 : Iss. 2 , Article 7.

DOI: 10.37796/2211-8039.1219

This Original Articles is brought to you for free and open access by BioMedicine. It has been accepted for inclusion in BioMedicine by an authorized editor of BioMedicine. 
Bioactivities and action mechanisms of active compounds from Hottuynia cordata THUNB on human lung cancer cells

\section{Cover Page Footnote}

This work was partially supported by the grant (CMU105-ASIA-14) from China Medical University, Taiwan. 


\title{
Bioactivities and action mechanisms of active compounds from Hottuynia cordata THUNB on human lung cancer cells
}

\author{
Yuh-Fung Chen ${ }^{\mathrm{a}, \mathrm{b}, \mathrm{c}, *}$, Wen-Hsin Chang ${ }^{\mathrm{a}}$, Huei-Yann Tsai ${ }^{\mathrm{b}}$, \\ Min-Min Lee ${ }^{c}$, Tian-Shang $\mathrm{Wu}^{\mathrm{d}}$ \\ ${ }^{a}$ Department of Pharmacology, China Medical University, Taichung, Taiwan \\ ${ }^{\mathrm{b}}$ Department of Pharmacy, China Medical University Hospital, Taichung, Taiwan \\ ${ }^{\mathrm{c}}$ Department of Food Nutrition and Health Biotechnology, Taichung, Taiwan \\ ${ }^{\mathrm{d}}$ Department of Pharmacy, Cheng Kung University, Tainan, Taiwan
}

\begin{abstract}
Background: Lung cancer is the leading cause of death in Taiwan for years. Besides the currently used chemotherapy, herbal medicine may play a role in the treatment of lung cancer. Hottuynia cordata THUNB (HC), one of the frequently used herbal medicine in Taiwan, has been widely used in various diseases. Review from literatures, HC has many effects, including anti-inflammatory, anti-viral, anti-bacterial, anti-SARS, and anti-tumor activities. However, there is no literatures describe its active compounds on lung cancer. This present study aims to evaluate the possible effect and action mechanism of active compounds from HC (aristolactam BII, aristolactam AII, and noraristolodione) on lung cancer. A549 lung cancer cell line was used to evaluate the effects of HC on the cell viability and possible anti-tumor effects.

Methods: We used A549 cells in the evaluation of anticancer activity. Cell viability, cell cycle, cell apoptosis and apoptosis related protein expression were studied.

Results: Active compounds from HC significantly inhibited A549 cell viability and induced accumulation of cell cycle at $\mathrm{S}$ or G2/M phase on A549 cells in a concentration-dependent manner, and induced A549 arrest at S or G2/M phase via increasing p21, p27, p53 and reducing cyclin-E, -A, cyclin-dependent kinase 2 (CDK2), cdc-2 (CDK1) protein expression. Additionally, HC induced A549 cell late apoptosis by up-regulating caspase-3, -8, Bax and decreasing Bcl-2 protein expression.

Conclusions: The anti-tumor effects of aristolactam BII, aristolactam AII, and noraristolodione on human lung carcinoma A549 cells were via cell cycle arrest and apoptosis.
\end{abstract}

Keywords: Hottuynia cordata THUnB, Anti-lung cancer, Aristolactam BII, Aristolactam AII, Noraristolodione, Cell cycle arrest, Apoptosis

\section{Introduction}

$\mathrm{L}$ ung cancer is the leading cause of cancer death in Taiwan and other countries for years [1]. In many countries in Europe and America, lung cancer is also cancer with the highest mortality rate [2]. How to prevent and effectively treat lung cancer to reduce its incidence and mortality is an important issue.
In addition to current chemotherapy, the use of Chinese herbal medicine may have a reference value for lung cancer [3]. Houttuynia cordata THuNB (Saururaceae; in abbreviation HC) is a very commonly used herbal medicine in Taiwan. The crude water layer of HC has anti-inflammatory activity $[4,5]$. It has anti-inflammatory activity against nitric oxide (NO) and tumor necrosis factor-alpha $(\mathrm{TNF}-\alpha)$ in the RAW264.7 cell line [3]. HC injection can inhibit carrageenan-induced pleurisy in rats and xylene-induced ear edema in mice [5]. The

Received 7 January 2021; revised 9 March 2021; accepted 10 March 2021.

Available online 1 June 2021

* Corresponding author at: Department of Pharmacology, School of Medicine, China Medical University, No. 91, Hsueh-Shih Road, Taichung 40404, Taiwan.

E-mail address: yfchen@mail.cmu.edu.tw (Y.-F. Chen). 
polyphenols in HC have antioxidant effects. For example, flavonoids can decompose the free radicals generated by oxidative stress in patients with diabetes [4-6]. Water extract of HC protects against bleomycin-induced pulmonary fibrosis [7]. HC can reduce viral plaque formation and reduce viral RNA synthesis, increase viral apoptosis [8]; it can also reduce the replication of herpes virus (HSV-2) achieve anti-viral infection activity [9]. Hot water extract of $\mathrm{HC}$ can effectively inhibit the growth of human leukemia cells [10].

Water layer extract of HC can stimulate the proliferation of mouse spleen lymphocytes by increasing the secretion of IL-2 and IL-10 of visceral lymphocytes, and at the same time increase the $\mathrm{CD}^{+}$and $\mathrm{CD}^{+} \mathrm{T}$ cells of the immune system; in terms of anti-virus, it shows inhibitory effects on SARS-CoV 3C-like protease (3CLpro) and RNAdependent RNA polymerase (RdRp) [11]. Six active alkaloids derived from the methanol extraction of HC are aristolactam BII, piperolactam A, aristolactam AII, norcepharadione $B$, cepharadione $B$, and splendidine, which can effectively inhibit the growth of five human cancer cell lines. Non-small cell lung cancer (A549), ovarian cancer (SK-OV-3), melanoma (SK-MEL-2), central nervous system cancer cells (XF-498) and colon cancer (HCT-15) are included $[12,13]$. However, there are no reposts regarding the action mechanisms of these active alkaloids on human lung cancer.

This study evaluated the possible effect and action mechanism of active alkaloids from HC on lung cancer. We used the A549 lung cancer cell line to evaluate HC's effects on cell viability and possible anti-tumor effects.

\section{Materials and Methods}

\subsection{Active alkaloids from $\mathrm{HC}$}

Five active alkaloids derived from the methanol extraction of Houttuynia cordata (HC), aristolactam BII, aristolactam AII, piperolactam A, norcepharadione $\mathrm{B}$, and noraristolodione were prepared and identified by Prof. Wu TS's lab.

\subsection{Chemicals and reagents}

RPMI cell culture medium, FBS (fetal bovine serum), P/S (penicillin-streptomycin), and trypan blue were purchased from Gibco BRL USA. DMSO (dimethyl sulfoxide), PI (propidium iodide), RNase A (ribonuclease A), BSA (bovine serum albumin), APS (ammonium persulfate), MTT (3-(4,5-dimethylthiazol-2-yl)-2,5-diphenyl-tetrazolium bromide),
Cellytic TM $M$ cell lysis reagent, Triton X-100 were from Sigma-Aldrich Chemical company, USA. TEMED (N-N-N'-N'-Tetramethylenediamine), Tween-20 (polyoxyethylenesorbitan monolaurate), trypran-EDTA, $\quad 40 \%$ acrylamide/BIS- ACRYLAMIDE (29:1 Ratio), 10X SDS (sodium dodecylsulfate) buffer, Tris (tris(hydroxymethy)aminomethane), 10X SDS-PAGE running buffer (TG-SDS buffer) were from Amersco company, USA. Apoptosis detection kit (PI/Annexin V-FITC) was from Becton Dickinson, USA. Western lightning chemiluminescene reagent plus (ECL) kit was from NEN Life Science, USA. Anti-cyclin A (ab7956), anticyclin E (ab7959), anti-CDk1/Cdc2 (ab6537), antiCdk2 (ab7954), Anti-p27K1P1 (ab47590), Anti-p21 (ab47452), goat anti-mouse IgG (HRP) horseradish peroxide conjugated antibody were from Abcam company. $\beta$-Actin (C4): sc-477778, caspase-3 (H277): sc-7418, caspase- 8 p20 (H-134):sc-7890, were from Santa Cruz biotechnology.

\subsection{Cell culture}

Human lung cancer A549 cells were from BCRC (the Bioresource Collection and Research Center) in Hsinchu, Taiwan. A549 cells were maintained in RPMI-1640 medium containing $100 \mathrm{ml} / \mathrm{L}$ FBS and 100,000 U/L penicillin/100 mg/L streptomycin.

\subsection{Cell viability}

A549 cells were plated onto 96-well plates and incubated with different concentrations $(12,5 \mu \mathrm{g} / \mathrm{ml}$, $25 \mu \mathrm{g} / \mathrm{ml}, 50 \mu \mathrm{g} / \mathrm{ml}$ ) of five alkaloids from $\mathrm{HC}$ (including aristolactam BII, aristolactam AII, piperolactam A, norcepharadione B, and noraristolodione) for $24 \mathrm{hr}$. MTT was added to each well and incubated for another $1 \mathrm{~h}$ at $37^{\circ} \mathrm{C}$. Dissolved the blue formazan product in $200 \mu \mathrm{l}$ DMSO for $15 \mathrm{~min}$, and then the plates were read using a spectrophotometric plate reader (Bio-Rad, Japan) at O.D. 570nm.

\subsection{Cell cycle distribution and apoptosis determination}

A549 cells were plated onto 12-well plates and incubated with different concentrations $(12,5 \mu \mathrm{g} / \mathrm{ml}$, $25 \mu \mathrm{g} / \mathrm{ml}, \quad 50 \mu \mathrm{g} / \mathrm{ml}$ ) of 3 alkaloids from $\mathrm{HC}$ (including aristolactam BII, aristolactam AII, and noraristolodione) for $24 \mathrm{hr}$. Fixed cells in $75 \%$ ethanol at $4{ }^{\circ} \mathrm{C}$ for overnight and resuspended in $1 \mathrm{X}$ PBS containing PI $(40 \mu \mathrm{g} / \mathrm{ml})$, RNase $(0.1 \mathrm{mg} / \mathrm{ml})$ and Triton X-100 $(0.1 \%)$ for $30 \mathrm{~min}$. Cell cycle distribution and apoptosis determination were 
analyzed by flow cytometry (FACS Calibur, Becton Dickinson, USA) as previously described [13].

\subsection{Western blotting}

A549 cells were plated onto $10-\mathrm{cm}$ plates and treated with various concentrations $(12,5 \mu \mathrm{g} / \mathrm{ml}, 25$ $\mu \mathrm{g} / \mathrm{ml}, 50 \mu \mathrm{g} / \mathrm{ml}$ ) of aristolactam BII, aristolactam AII, and noraristolodione for $24 \mathrm{hr}$. Total cell lysates were prepared as previously described [13]. Applied forty $\mu \mathrm{g}$ of total protein to SDS-PAGE and transferred onto a PVDF (polyvinylidene fluoride) membrane. Then, incubated the blots with the appropriate dilution of specific monoclonal antibodies for cyclin E, cyclin A, CDK2, cdc 2, p21, p27, p53, caspase 3, caspase 8, Bax and Bcl-2. Using enhanced chemiluminescence kits (ECL kit) to detect protein expressions [13].

\subsection{Statistical analysis}

The experiments were performed at least in triplicate and all data were expressed as the mean \pm standard error. Student's $t$-test and one-way ANOVA followed by Dunnett's test were used for single variable comparison and multiple variable comparisons, respectively. Significance was considered when $P<0.05$.

\section{Results}

\subsection{Effects of alkaloids from HC on the viability of A549 cells}

Various doses $(12.5 \mu \mathrm{g} / \mathrm{ml}, 25 \mu \mathrm{g} / \mathrm{ml}, 50 \mu \mathrm{g} / \mathrm{ml})$ of active compounds (aristolactam BII, aristolactam AII, piperolactam A, norcepharadione B, and noraristolodione) from HC treated with A549 cells for $24 \mathrm{~h}$, and the cell viability was detected by MTT tests. These compounds showed a dose-dependent inhibition on the cell viability of human lung cancer A549 cells, $* P<0.05, * * P<0.01$, and ${ }^{* * *} P<0.001$ (as shown in Fig. 1).

\subsection{Effects of alkaloids from HC on the cell cycle of A549 cells}

The DNA content of the cell cycle is highest in the G1 phase, followed by the S phase, and the G2/M phase is the least. Compared to the control group, the alkaloids aristolactam BII and aristolactam AII produced the $S$ phase and G2/M phase accumulation $\left(* P<0.05,{ }^{* *} P<0.01\right.$, and $* * * P<0.001$, as shown in Fig. 2 and Fig. 3), and noraristolodione only caused accumulation in the $S$ phase $\left({ }^{* *} P<0.01\right.$, as shown in Fig. 4)

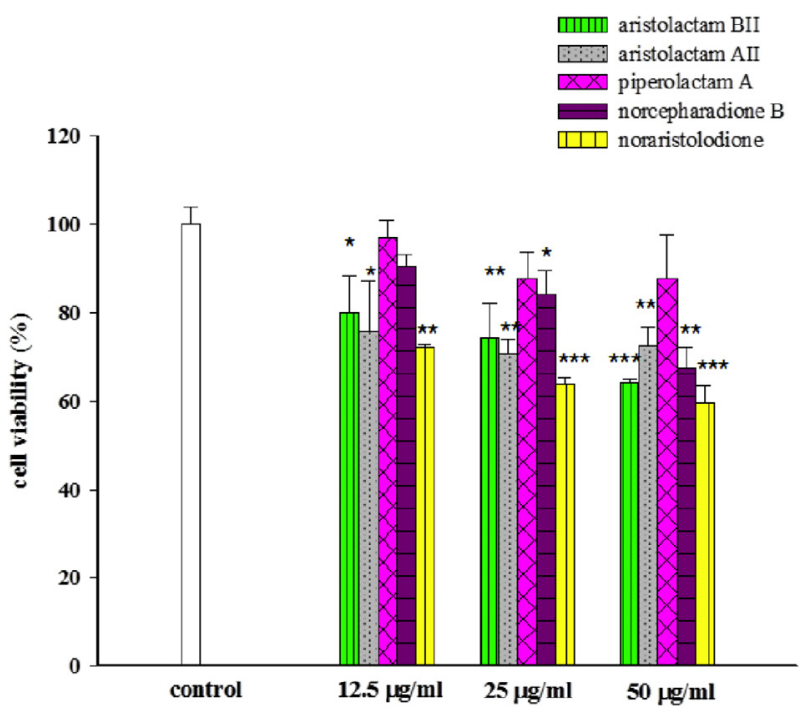

Fig. 1. Effects of active compounds (aristolactam BII, aristolactam AII, piperolactam $A$, norcepharadione $B$, and noraristolodione) on cell viability of human lung cancer A549 cells. Various concentrations (12.5 $\mu \mathrm{g} / \mathrm{ml}, 25$ $\mu \mathrm{g} / \mathrm{ml}, 50 \mu \mathrm{g} / \mathrm{ml}$ ) of these active compounds treated with A549 cells for 24 $h$. Detected the cell viability by MTT tests. Results were represented as vertical bars and mean \pm S.E. $* P<0.05, * * P<0.01, * * * P<0.001$ was considered statistically significant compared to the control group.

3.3. Effect of alkaloids from HC on the cell cyclerelated and apoptosis-related proteins of A549 cells

Alkaloids (aristolactam BII, aristolactam AII, and noraritoldione) from $\mathrm{HC}$ decreased the cyclin $\mathrm{A}$, cyclin E, CDK 2, and Cdc2 (CDK1) proteins related to the $S$ phase and $\mathrm{G} 2 / \mathrm{M}$ phase of the cell cycle in a dose-dependent manner $\left(* P<0.05,{ }^{* *} P<0.01\right.$, and $* * * P<0.001$, as shown in Figs. $5-7)$. Alkaloids from HC concentration-dependent increased the



Fig. 2. Effects of different concentrations $(12.5 \mu \mathrm{g} / \mathrm{ml}, 25 \mu \mathrm{g} / \mathrm{ml}$, and $50 \mu \mathrm{g} / \mathrm{ml}$ ) of aristolactam BII on A549 cell cycle distribution. Aristolactam BII treatment for $24 \mathrm{~h}$ altered A549 cell-cycle distribution and arrested at S/G2/M phase. Results were represented as vertical bars and mean \pm S.E. $* P<0.05,{ }^{*} P<0.01, * * * P<0.001$ was considered statistically significant compared to the control group. 




Fig. 3. Effects of different concentrations $(12.5 \mu \mathrm{g} / \mathrm{ml}, 25 \mu \mathrm{g} / \mathrm{ml}$, and 50 $\mu \mathrm{g} / \mathrm{ml}$ ) of aristolactam AII on A549 cell cycle distribution. Aristolactam AII treatment for $24 \mathrm{~h}$ altered A549 cell-cycle distribution and arrested at S/G2/M phase. Results were represented as vertical bars and mean \pm S.E. $* P<0.05, * * P<0.01, * * * P<0.001$ was considered statistically significant compared to the control group.

apoptosis-related protein p21, p27, P53, caspase 3 and caspase 8 , and Bax. However, the survival protein Bcl-2 was reduced $(* P<0.05, * * P<0.01$, and $* * * P<0.001$, as shown in Figs. 5-7).

\section{Discussion}

According to previous reports, Houttuynia cordata (HC) does affect some human cancer cell lines, such as non-small cell lung cancer (A549 cells), ovarian cancer (SK-OV-3 cells), and melanoma (SK-MEL-2 cells) $[12,13]$. HC has anti-growth effects on central nervous system cancer cells (XF-498 cells) and colon cancer (HCT-15 cells) [12]. HC has anti-lung cancer

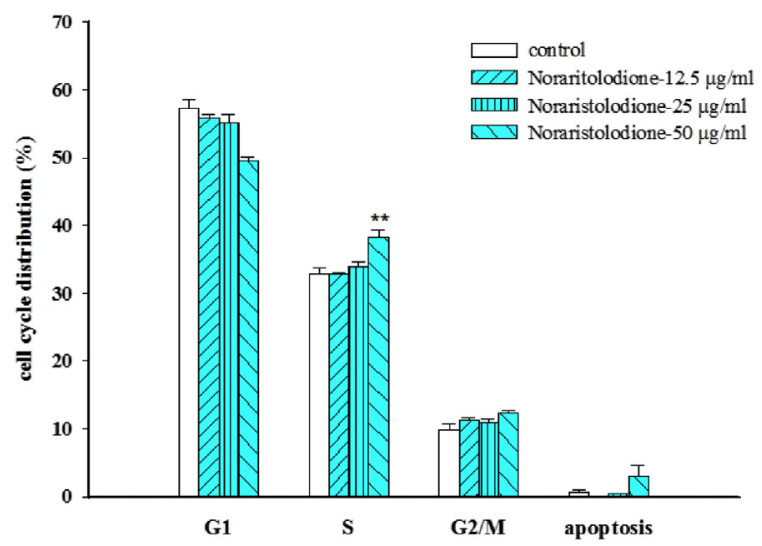

Fig. 4. Effects of different concentrations $(12.5 \mu \mathrm{g} / \mathrm{ml}, 25 \mu \mathrm{g} / \mathrm{ml}$, and 50 $\mu \mathrm{g} / \mathrm{ml}$ ) of noraristolodione on A549 cell cycle distribution. Noraristolodione treatment for $24 \mathrm{~h}$ altered A549 cell-cycle distribution and arrested at S/G2/M phase. Results were represented as vertical bars and mean \pm S.E. $* P<0.05, * * P<0.01, * * * P<0.001$ was considered statistically significant compared to the control group. activity by interfering cell cycle; it modulates G0/G1 arrest and stimulates the Fas/CD95 protein level [13]. Thus, leads to caspase- 8 and caspase-3 activation and resulting in the induction of apoptosis in human lung cancer A549 cells [13]. At present, chemotherapy and radiotherapy are mostly used for the treatment of lung cancer in clinical practice [14,15], all of which have side effects. In order to provide a reference for the clinical application of $\mathrm{HC}$, the anti-cancer mechanism of active compounds from HC is studied.

Previous results show $\mathrm{HC}$ extract modulates $\mathrm{G}_{0} /$ $\mathrm{G}_{1}$ arrest and Fas/CD95-mediated death receptor apoptotic cell death in human lung cancer A549 cells [13]. The mechanism of HC extract on A549 cells is reducing the expression of cyclin D1, cyclin E, cyclin $\mathrm{A}$, and CDK4/CDK6 and CDK2 proteins in the cell cycle, and increasing the expression of p27KIP1 Arrest A549 cells in the G1/S phase, and activate the external pathways of caspase 3 and caspase 8 to promote cell apoptosis [13].

There were about 44 compounds isolated from the whole plant of HC [16]. Based on the toxic effect of the crude extracts on A549 cells, it may be derived from the alkaloids contained in HC. After testing five kinds of alkaloids from $\mathrm{HC}$ revealed that three of them have a significant inhibitory effect on A549 cells. Treated A549 cells with different concentrations of these alkaloids revealed a decrease of the survival rate (as shown in Fig. 1). These three alkaloids, aristolactam BII, aristolactam AII and noraristolodione, were used to explore their effects on A549 cells. Under the treatment of aristolactam BII and aristolactam AII, A549 cells were found to accumulate in $S$ phase or G2/M phase, that is, cell cycle growth stopped in S phase or G2/M (as shown in Figs. 2 and 3). Under the treatment of noraristolodione, the cell cycle of A549 cells was arrested in S phase (as shown in Fig. 4), and treated these alkaloids at $50 \mu \mathrm{g} / \mathrm{ml}$ will promote A549 cell apoptosis.

The protein expression level results revealed that aristolactam BII and aristolactam AII dose-dependently decreased the cyclin E, cyclin A, CDK 2, and Cdc 2 proteins in the $S$ phase or G2/M phase. However, aristolactam BII and aristolactam AII dose-dependently increased the p21, p27, and p53 of the cell cycle protein, and the apoptosis-related proteins caspase 3, caspase 8, Bax. Aristolactam BII and aristolactam AII dose-dependently decreased Bcl-2 expression level, as shown in Figs. 5 and 6. As to noraristolodione, it dose-dependently inhibited cyclin E, cyclin A, CDK 2, and dose-dependently decreased the p21, p27, p53 of the cell cycle protein. It dose-dependently increased caspase 3 , caspase 8 , 
44 Y.-F. CHEN ET AL

(A)

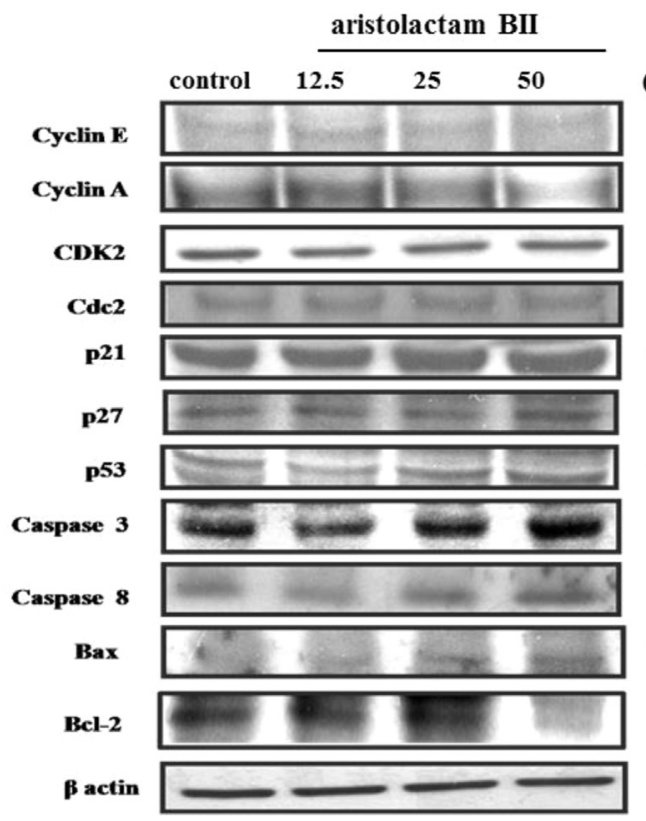

(B)

\begin{tabular}{|c|c|c|c|c|}
\hline \multirow{3}{*}{$\begin{array}{l}(\mu \mathrm{g} / \mathrm{ml}) \\
47 \mathrm{KDa}\end{array}$} & control & 12.5 & 25 & $50(\mu \mathrm{g} / \mathrm{ml})$ \\
\hline & \multicolumn{4}{|c|}{ Protein / $\beta$ actin level (\%) } \\
\hline & 100 & $96.45 \pm 0.69^{* *}$ & $92.77 \pm 0.93^{* *}$ & $88.47 \pm 2.42^{* *}$ \\
\hline 49KDa & 100 & $99.03 \pm 1.62$ & $93.09 \pm 1.63^{\star}$ & $83.86 \pm 2.08^{* t}$ \\
\hline 35KDa & 100 & $97.04 \pm 2.11$ & $93.86 \pm 1.29^{* *}$ & $92.13 \pm 2.89$ \\
\hline 34KDa & 100 & $99.34 \pm 4.66$ & $92.72 \pm 3.32$ & $90.75 \pm 4.25$ \\
\hline 32KDa & 100 & $97.47 \pm 0.58$ & $103.10 \pm 2.72$ & $106.66 \pm 4.44$ \\
\hline 27KDa & 100 & $108.44 \pm 0.68^{t+1}$ & $110.67 \pm 2.65$ * & $117.49 \pm 2.95^{*+}$ \\
\hline 53KDa & 100 & $101.18 \pm 0.40$ & $117.21 \pm 4.71^{*}$ & $127.31 \pm 2.49^{27 \pi}$ \\
\hline 37KDa & 100 & $104.60 \pm 1.60^{*}$ & $106.83 \pm 0.29^{\star \pm t}$ & $118.93+0.95^{\text {t1t }}$ \\
\hline 20KDa & 100 & $118.39 \pm 5.45^{*}$ & $120.74 \pm 4.90^{*}$ & $131.12 \pm 3.24^{4.5}$ \\
\hline 23KDa & 100 & $107.43 \pm 1.83^{*}$ & $109.84 \pm 1.03^{\text {t* }}$ & $124.47 \pm 1.65^{\text {t* }}$ \\
\hline 28KDa & 100 & $83.50 \pm 0.53^{m+}$ & $80.11 \pm 0.75^{+1+}$ & $74.31 \pm 0.73^{+1+.}$ \\
\hline
\end{tabular}

43KDa

Fig. 5. Various concentrations $(12.5 \mu \mathrm{g} / \mathrm{ml}, 25 \mu \mathrm{g} / \mathrm{ml}$, and $50 \mu \mathrm{g} / \mathrm{ml})$ of aristolactam BII treated A549 cells for $24 \mathrm{~h}$ suppressed CDKs, cyclins, Bcl-2 protein expression and up-regulation of apoptotic protein (caspase 3, caspase 8, p21, p27, p53, and Bax) expression (A). Protein/ $\beta$ actin level (\%) presented in (B). The experiments were done in triplicate with similar results and used the blot of $\beta$ actin as a loading control. $* P<0.05, * * P<0.01$, ${ }^{* * *} P<0.001$ was considered statistically significant compared to the control group.

(A)

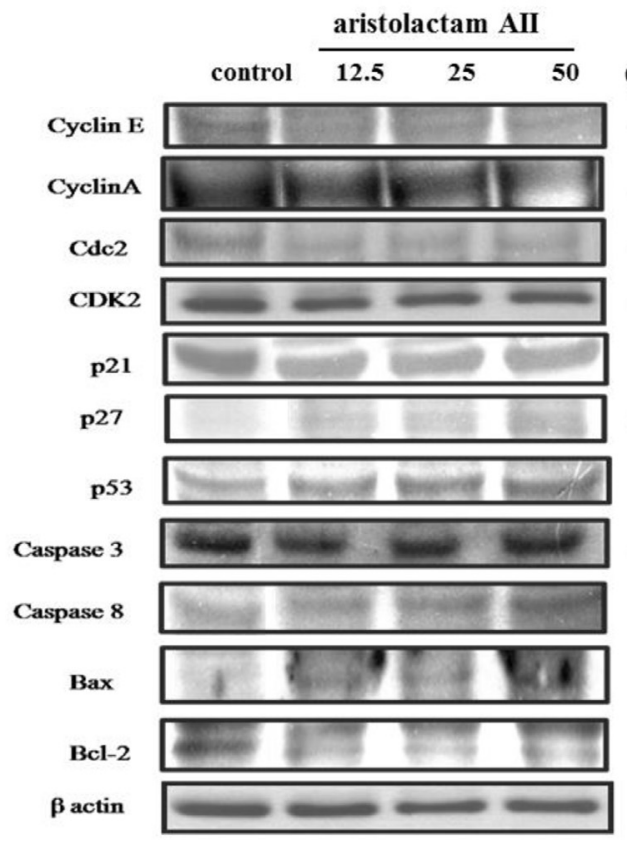

(B)

\begin{tabular}{|c|c|c|c|c|}
\hline \multirow{3}{*}{$\begin{array}{l}(\mu \mathrm{g} / \mathrm{ml}) \\
47 \mathrm{KDa}\end{array}$} & control & 12.5 & 25 & $50(\mu \mathrm{g} / \mathrm{ml})$ \\
\hline & \multicolumn{4}{|c|}{ Protein / $\beta$ actin level $(\%)$} \\
\hline & 100 & $96.45 \pm 0.69^{*+}$ & $92.77 \pm 0.93^{* *}$ & $88.47 \pm 2.42^{* *}$ \\
\hline $49 \mathrm{KDa}$ & 100 & $99.03 \pm 1.62$ & $93.09 \pm 1.63^{\star}$ & $83.86 \pm 2.08^{* t}$ \\
\hline 34KDa & 100 & $97.04 \pm 2.11$ & $93.86 \pm 1.29^{* t}$ & $92.13 \pm 2.89$ \\
\hline $35 \mathrm{KDa}$ & 100 & $99.34 \pm 4.66$ & $92.72 \pm 3.32$ & $90.75 \pm 4.25$ \\
\hline $32 \mathrm{KDa}$ & 100 & $97.47 \pm 0.58$ & $103.10 \pm 2.72$ & $106.66 \pm 4.44$ \\
\hline $27 \mathrm{KDa}$ & 100 & $108.44 \pm 0.68^{* t+7}$ & $110.67 \pm 2.65^{*}$ & $117.49 \pm 2.95^{\prime \prime}$ \\
\hline $53 \mathrm{KDa}$ & 100 & $101.18 \pm 0.40$ & $117.21 \pm 4.71^{*}$ & $127.31 \pm 2.49^{\star 2 *}$ \\
\hline $37 \mathrm{KDa}$ & 100 & $104.60 \pm 1.60^{\star}$ & $106.83 \pm 0.29^{\star \star \star *}$ & $118.93 \pm 0.95^{\mathrm{tz} t}$ \\
\hline $54 \mathrm{KDa}$ & 100 & $118.39 \pm 5.45^{*}$ & $120.74 \pm 4.90^{*}$ & $131.12 \pm 3.24^{4 t+t}$ \\
\hline $23 \mathrm{KDa}$ & 100 & $107.43 \pm 1.83^{*}$ & $109.84 \pm 1.03^{+* *}$ & $124.47 \pm 1.65^{+1 .}$ \\
\hline $28 \mathrm{KDa}$ & 100 & $83.50 \pm 0.53^{m+}$ & $80.11 \pm 0.75^{1+t}$ & $74.31 \pm 0.73^{m+}$ \\
\hline
\end{tabular}

43KDa

Fig. 6. Various concentrations ( $12.5 \mu \mathrm{g} / \mathrm{ml}, 25 \mu \mathrm{g} / \mathrm{ml}$, and $50 \mu \mathrm{g} / \mathrm{ml}$ ) of aristolactam AII treated A549 cells for $24 \mathrm{~h}$ suppressed CDKs, cyclins, Bcl-2 protein expression and up-regulation of apoptotic protein (caspase 3, caspase 8, p21, p27, p53, and Bax) expression (A). Protein/ $\beta$ actin level (\%) presented in (B). The experiments were done in triplicate with similar results and used the blot of $\beta$ actin as a loading control. $* P<0.05, * * P<0.01$, ${ }^{* * *} P<0.001$ was considered statistically significant compared to the control group. 
(A)

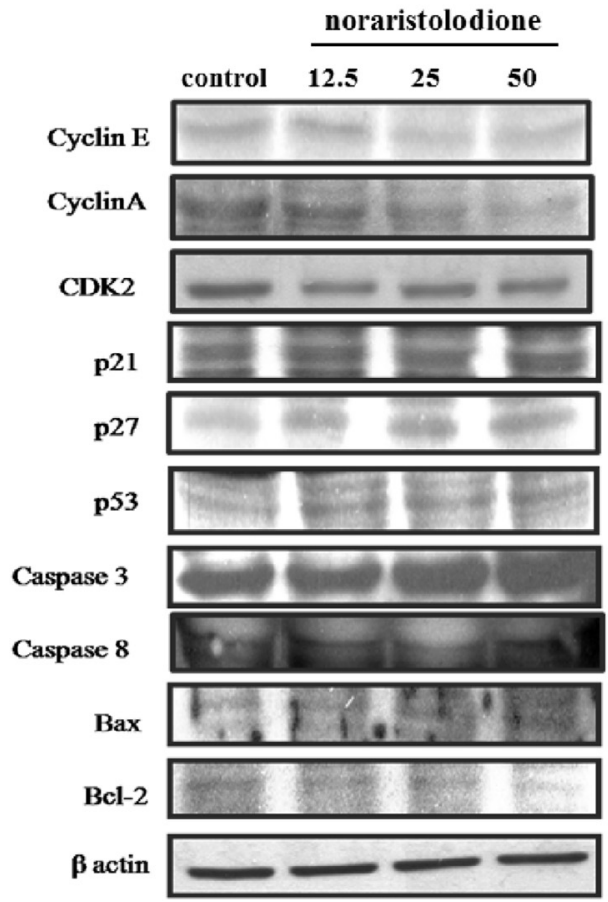

(B)

\begin{tabular}{|c|c|c|c|c|}
\hline \multirow[b]{2}{*}{$\mu \mathrm{g} / \mathrm{ml})$} & contro & 12.5 & 25 & $50(\mu \mathrm{g} / \mathrm{ml})$ \\
\hline & \multicolumn{4}{|c|}{ Protein / $\beta$ actin level (\%) } \\
\hline $47 \mathrm{KDa}$ & 100 & $93.27 \pm 9.0 \sigma^{\text {th }}$ & $90.65 \pm 1.09^{ \pm \pi}$ & $82.48 \pm 1.34^{4 n t}$ \\
\hline $49 \mathrm{KDa}$ & 100 & $95.50 \pm 1.91$ & $87.09 \pm 3.98^{*}$ & $70.13 \pm 1.46^{\ldots \ldots}$ \\
\hline $35 \mathrm{KDa}$ & 100 & $95.98 \pm 1.58$ & $91.08 \pm 5.73$ & $91.95 \pm 3.93$ \\
\hline 32KDa & 100 & $109.90 \pm 1.7 \sigma^{+*}$ & $113.60 \pm 2.20^{+*}$ & $117.21 \pm 2.76^{+*}$ \\
\hline $27 \mathrm{KDa}$ & 100 & $111.56 \pm 4.88^{\star *}$ & $121.69 \pm 3.26^{*}$ & $128.93 \pm 5.22^{*+}$ \\
\hline $53 \mathrm{KDa}$ & 100 & $103.47 \pm 1.52$ & $105.92 \pm 1.34^{ \pm}$ & $116.97 \pm 1.26^{\text {ttrt }}$ \\
\hline $37 \mathrm{KDa}$ & 100 & $110.31 \pm 2.90^{\star}$ & $115.03 \pm 3.28^{\star}$ & $123.19 \pm 4.03^{\star \star}$ \\
\hline $54 \mathrm{KDa}$ & 100 & $106.71 \pm 2.46$ & $110.13 \pm 1.26^{\mathrm{tt}}$ & $121.88 \pm 4.50^{* t}$ \\
\hline $23 \mathrm{KDa}$ & 100 & $107.03 \pm 1.48^{\star \star}$ & $115.37 \pm 3.36^{\star}$ & $120.15 \pm 3.24^{\star \star}$ \\
\hline $28 \mathrm{KDa}$ & 100 & $92.84 \pm 3.22$ & $77.96 \pm 1.16^{m+}$ & $75.10 \pm 0.87$ \\
\hline
\end{tabular}

$43 \mathrm{KDa}$

Fig. 7. Various concentrations $(12.5 \mu \mathrm{g} / \mathrm{ml}, 25 \mu \mathrm{g} / \mathrm{ml}$, and $50 \mu \mathrm{g} / \mathrm{ml})$ of noraristolodione treated A549 cells for $24 \mathrm{~h}$ suppressed CDKs, cyclins, Bcl-2 protein expression and up-regulation of apoptotic protein (caspase 3, caspase 8, p21, p27, p53, and Bax) expression (A). Protein/ $\beta$ actin level (\%) presented in (B). The experiments were done in triplicate with similar results and used the blot of $\beta$ actin as a loading control. $* P<0.05, * * P<0.01$, ${ }^{* * *} P<0.001$ was considered statistically significant compared to the control group.

Bax protein level and dose-dependently decreased Bcl-2 expression (as shown in Fig. 7). p53 is a transcription factor that is responsible for regulating the balance between normal cell growth and apoptosis. There are a large number of variability p 53 in cancer cells $[17,18]$. According to the experimental results,



Fig. 8. Proposed model of alkaloids from Hottuynia cordata THuNB (in abbreviation HC) modulates S/G2/M arrest and induces apoptotic cell death on human lung cancer A549 cells. the alkaloids in HC can inhibit the activity of A549 cells by influencing cell cycle-related proteins and apoptosis-related proteins. It may be that $\mathrm{p} 21 / \mathrm{p} 27$ increase by activating $\mathrm{p} 53$ on the one hand, allowing A549 cell cycle arrest; on the other hand, by increasing the expression of Bax, caspase 8, and caspase 3 and reducing Bcl-2 activity [19].

\section{Conclusions}

From the above results, alkaloids from $\mathrm{HC}$ reduced cyclin $\mathrm{E}$, cyclin $\mathrm{A}, \mathrm{CDK} 2$, and Cdc2 (CDK1) of the cell cycle of A549 cells, and increased the expression of p21cip, p27KIP1, and p53 proteins, so that A549 cells were stagnant. In the $S$ or $\mathrm{G} 2 / \mathrm{M}$ phase, while increasing caspase 3 , caspase 8 , Bax and reducing the protein expression of Bcl-2. A549 cells underwent apoptosis through internal and external pathways. The anti-tumor effects of aristolactam BII, aristolactam AII, and noraristolodione on human lung cancer A549 cells were via cell cycle arrest and apoptosis (as shown in Fig. 8).

\section{Specific author contributions}

YFC conceived for the study, participated in its design, and drafted the manuscript. WHC performed the cell studies and plotted data figures. 
TSW helped to isolate alkaloids from Hottuynia cordata THUNB. YFC and HYT performed data analysis, helped to plot figures and revised the manuscript. HYT and MML conceived for the study and helped to revise the manuscript.

\section{Conflict of interest statement}

The authors wish to declare no conflicts of interest on this work.

\section{Acknowledgements}

This work was partially funded by China Medical University, Taiwan (CMU 105-ASIA-14).

\section{References}

[1] Kuo CN, Liao YM, Kuo LN, Tsai HJ, Chang WC, Yen Y. Cancers in Taiwan: Practical insight from epidemiologu, treatments, biomarkers, and cost. J Formosan Med Associ 2020;119:1731-41.

[2] Sung H, Ferlay J, Siegel RL, Laversanne M, Soerjomataram I, Jemal A, Bray F. Global Csncer Statistics 2020: GLOBOCAN Estimates of Incidence and Mortality Worldwide for 36 Cancers in 185 Countries. CA Cancer J Clin 2021:1-41.

[3] Huang CY, Ju DT, Chang CF, Reddy PM, Velmurugan BK. A review on the effects of current chemotherapy drugs and natural agents in treating non-small cell lung cancer. BioMedicine 2017;7(4):12-23.

[4] Toda S. Antioxidative effects of polyphenols in leaves of Houttuynia cordata on protein fragmentation by copperhydrogen peroxide in vitro. J Med Food 2005;8(2):266-8.

[5] Lu HM, Liang YZ, Yi LZ, Wu XJ. Anti-inflammatory effect of Houttuynia cordata injection. J Ethnopharm 2006;104(1-2): 245-9.

[6] Chen YY, Liu JF, Chen CM, Chao PY, Chang TJ. A study of the antioxidative and antimutagenic effects of Houttuynia cordata $\mathrm{T}_{\mathrm{HUNB}}$. Using an oxidized frying oil-fed model. $\mathrm{J}$ Nutri Sci Vitamin 2003;49(5):327-33.
[7] Ng LT, Yen FL, Liao CW, Lin CC. Protective effect of Houttuynia cordata extract on bleomycin-induced pulmonary fibrosis in rats. Am J Chin Med 2007;35(3):465-75.

[8] Lin TY, Liu YC, Jheng JR, et al. Anti-enterovirus 71 activity screening of Chinese herbs with anti-infection and inflammation activities. Am J Chin Med 2009;37(1):143-58.

[9] Chiang LC, Chang JS, Chen CC, Ng LT, Lin CC. Anti-Herpes simplex virus activity of Bidens pilosa and Houttuynia cordata. Am J Chin Med 2003;31(3):355-62.

[10] Chang JS, Chiang LC, Chen CC, Liu LT, Wang KC, Lin CC. Antileukemic activity of Bidens pilosa L. var. minor (Blume) Sherff and Houttuynia cordata $\mathrm{T}_{\mathrm{HUNB}}$. Am J Chin Med 2001; 29(2):303-12.

[11] Lau KM, Lee KM, Koon CM, et al. Immunomodulatory and anti-SARS activities of Houttuynia cordata. J Ethnopharm 2008;118(1):79-85.

[12] Kim SK, Ryu SY, No J, Choi SU, Kim YS. Cytotoxic alkaloids from Houttuynia cordata. Arch Pharma Res 2001;24(6):518-21.

[13] Chen YF, Yang JS, Chang W, Tsai SC, Peng SF, Zhou YR. Houttuynia cordata $\mathrm{T}_{\mathrm{HUNB}}$ extract modulates G0/G1 arrest and Fas/CD95-mediated death receptor apoptotic cell death in human lung cancer A549 cells. J Biomed Sci 2013; 20(1):18.

[14] Rixe O, Spano JP, Seigneur J. Chemotherapy of non-small cell lung cancer: non-cisplatin based combinations. Anticancer Drugs 2000;11(Suppl 1):S29-33.

[15] Liu X, Wang B, Fu X. [Clinical study on treatment of advanced non-small cell lung cancer with Chinese herbal medicine combined with synchronous radio- and chemotherapy]. Chin J Integr Med 2000;20(6):427-9.

[16] Chou SC. The Constituents of the Houttuynia cordata $\mathrm{T}_{\mathrm{HUNB}}$ Master Theses. Department of Chemistry, National ChengKung University; 2009.

[17] Wierod L, Rosseland CM, Lindeman B, et al. Activation of the p53-p21 (Cip1) pathway is required for CDK2 activation and S-phase entry in primary rat hepatocytes. Oncogene 2008;27(19):2763-71.

[18] Katiyar SK, Meeran SM, Katiyar N, Akhtar S. p53 Cooperates berberine-induced growth inhibition and apoptosis of non-small cell human lung cancer cells in vitro and tumor xenograft growth in vivo. Mole Carcinog 2009; 48(1):24-37.

[19] Zuckerman V, Wolyniec K, Sionov RV, Haupt S, Haupt Y. Tumor suppression by p53: the importance of apoptosis and cellular senescence. J Pathol 2009:2584-97. 